\title{
Article \\ Effects of Corporate Entrepreneurship Dimensions on Organizational Performance: Case of Small and Medium Enterprises in Holeta Town, Ethiopia
}

\author{
Gemechu Abdissa ${ }^{1, *}$, Abebe Ayalew ${ }^{2} \mathbb{D}$, Csaba Bálint Illés ${ }^{3}$ and Anna Dunay ${ }^{3}$ \\ 1 Doctoral School of Economics and Regional Sciences, Hungarian University of Agriculture and Life Sciences, \\ 2100 Gödöllő, Hungary \\ 2 Department of Management, Colleges of Business and Economics, Ambo University, \\ Ambo (+251)19, Ethiopia; abebe.ayalew@ambou.edu.et \\ 3 Institute of Economics Sciences, Hungarian University of Agriculture and Life Sciences, \\ 2100 Gödöllő, Hungary; Illes.Balint.Csaba@uni-mate.hu (C.B.I.); dunay.anna@uni-mate.hu (A.D.) \\ * Correspondence: gemechu.mtu@gmail.com; Tel.: +36-702-130-893
}

Citation: Abdissa, G.; Ayalew, A.; Illés, C.B.; Dunay, A. Effects of Corporate Entrepreneurship Dimensions on Organizational Performance: Case of Small and Medium Enterprises in Holeta Town, Ethiopia. J. Open Innov. Technol. Mark. Complex. 2021, 7, 234. https:// doi.org/10.3390/joitmc7040234

Received: 30 October 2021 Accepted: 12 November 2021 Published: 2 December 2021

Publisher's Note: MDPI stays neutral with regard to jurisdictional claims in published maps and institutional affiliations.

Copyright: (c) 2021 by the authors. Licensee MDPI, Basel, Switzerland. This article is an open access article distributed under the terms and conditions of the Creative Commons Attribution (CC BY) license (https:/ / creativecommons.org/licenses/by/ $4.0 /)$.

\begin{abstract}
Small and medium enterprises are paying the lion's share in the innovation-based economy of today's competitive business environment. To this effect, this study observed the effects of corporate entrepreneurship (CE) dimensions on the performance of SMEs in the town of Holeta, Ethiopia. We used both descriptive and survey research designs to meet the specified target of the study. The researchers employed both primary and secondary data sources; the former were collected from 173 participants using both primary and secondary data. The result of this study indicates that all of the explanatory variables used were statistically significant and had a positive relationship with the performance of SMEs. Thus, we recommend that owners of small and medium enterprises pay special attention to practicing CE to increase their business performance, sustainability, and competitiveness. Entrepreneurs should also come up with new and attractive product and service features to take high market shares. Furthermore, forecasting potential challenges for firms and devising possible ways of solving the situation in advance can safeguard businesses from failure.
\end{abstract}

Keywords: corporate entrepreneurship; performance; small and medium enterprises; innovativeness; proactiveness; risk taking

\section{Introduction}

Corporate entrepreneurship (CE) is often considered as the concept of supporting workers to think and behave like entrepreneurs inside an existing organizational structure. Corporate entrepreneurship is the creation of new businesses within an existing organization through innovation or transforming the business by renewing the company's strategy to increase business profits to overcome competition in the market [1-4]. According to Parker [5], corporate entrepreneurship is developing new ventures or taking advantage of novel prospects in external situations to create economic value. Currently, several business organizations are inclined towards corporate entrepreneurship (CE) to cope with today's global market competition [6]. Corporate entrepreneurship is also seen as an approach for renewing an organization because, along with innovation, there is an existing drive toward new ventures [7]. As CE is established within an enterprise, there is significant economic growth and wealth creation at all stages of the organizational life cycle [8]. Accordingly, firms that practice entrepreneurial actions at the early stages become more successful in their life span than other enterprises [9-12].

According to Mohamad et al. [13], CE increases the performance of a business firm regardless of its nature and size. Adeyeye (2016) indicated in his study, as cited in [14], that $\mathrm{CE}$ is "increasingly known for its model for successful competition, survival, as well as growth for enterprises". The significance of corporate entrepreneurship has therefore 
received a growing reputation in recent years [6], as it helps managers to appreciate the importance of developing employees' entrepreneurial mindset and motivating them to participate in the innovative activities of organizations [15]. Contemporary businesses are continually in search of the means to be distinguished by adopting innovation and creativity to have a competitive advantage. As small firms grow, it is necessary to incorporate CE in their strategic management while simultaneously reinventing it, as well as achieving their objectives, even in antagonistic situations [11].

Small and medium enterprises are fueling the sustainable economic growth of developed, emerging, transitioning, and low-income countries; their survival and sustainability are becoming a crucial issue [16]. The Ethiopian government has devised a special program to promote small and medium enterprises, which is an indication that developmental policies are inclined towards SMEs to sustain the fast growth discovered in the country [17]. However, each year, many SMEs enter the business sector, but a number of them are lost and experience organizational death [18], which indicates that there is a missing link between the use of CE and its implementation in SMEs. Moreover, large organizations drive the attention of scholars, and most studies have focused on how to sustain their operation, as one firm can have a large influence on the economy [19-22]; however, small and medium enterprises receive little attention from researchers and practitioners from this field, despite their contribution to the economy on a collective basis [23].

Therefore, we intend on filling the research gaps in the area of corporate entrepreneurship dimensions and their effects on organizational performance through the following:

- Assessing the effects of the innovative dimension of CE on the performance of small and medium enterprises;

- Assessing the effects of the proactive dimension of $\mathrm{CE}$ on the performance of small and medium enterprises;

- Assessing the effects of the risk taking dimension of CE on the performance of small and medium enterprises.

In line with the specific objectives stated above, the findings of this study contribute valuable significance to scientific knowledge and the community. Concerning scientific knowledge, this study will aid the government in policy development and implementation. This study will also contribute to the academic literature and help other researchers who wish to conduct their studies on similar issues. The results of this study will provide many companies with a systematic method of increasing their innovation capabilities; it can provide insights not available to competitors, which is a valuable source of ongoing competitive advantage. Finally, this study will allow employees to pursue their ideas and opportunities for the business that lead to higher levels of job satisfaction. A result of this would be lower levels of staff turnover.

\section{Related Literature Reviews and Proposed Hypotheses}

\subsection{An Overview of Corporate Entrepreneurship}

Since its commencement as a field of study, corporate entrepreneurship has passed through different stages and has a strong theoretical background [24]. The concept of corporate entrepreneurship has shown progress in the past five decades, in which significant variations of its definition have been noted [25]. Corporate entrepreneurship was thought of as a branch of enterprise revitalization in the 1980s, which was a very simple definition at that time [26].

The popular definition of corporate entrepreneurship in the 1990s, which still dominates the landscape, is as follows: "a process whereby an individual or group of individuals in an association with existing organizations create a new organization or instigate renewal or innovation that can facilitate innovation within the company" [27]. Kuratko et al. [28] stated that $C E$ is a concept that refers to the creative ability of individuals in an organization irrespective of the structure and type of the business. The authors also indicated that business ventures, new product and service innovation, and new administrative techniques are the outcomes of corporate entrepreneurship within an organization. 
According to Guth and Ginsberg, [29], as cited in Ravjee and Mamabolo, [30], corporate entrepreneurship has two main, yet complementary features: strategic entrepreneurship and the creation of new ventures. Kuratko et al. [28] clearly showed the difference between the two approaches by indicating that the former is regarded as recognition of actions in the functioning of the organization, whereas the latter is referred to as the establishment of other firms which have not existed before.

Ravjee and Mamabolo [30] indicated that the 1990s was an era in which renewal, innovation, risk taking, proactiveness, and corporate venturing were taken as the central argument for corporate entrepreneurship dimensions. Moreover, researchers in the 21st century have confirmed that corporate entrepreneurship is a base for firms' profitable growth by enabling a sustainable competitive advantage [31,32]. Eric-Nielsen [33] reaffirmed that a reliable source in sustaining and coping with all the new features of a market in the course of business operation is the aptitude to develop entrepreneurially focused workers at all positions of the organization. Organizational learnedness and knowledge transfer are how the theoretical standpoint of the corporate entrepreneurship concept can be transformed into a practical contribution by stimulating specific types of entrepreneurial initiatives [31]. Describtion of CE dimensions and definition given by different researchers was compiled in the following Table 1.

Table 1. Dimensions of CE with their definitions.

\begin{tabular}{|c|c|c|}
\hline Writers & Definitions & Dimensions \\
\hline M. H. Morris and G. W. Paul [34] & $\begin{array}{l}\text { CE is defined as organizational revitalization } \\
\text { to create a unique organization in } \\
\text { collaboration with all stakeholders in which } \\
\text { the firm assumes the calculated risk in the } \\
\text { course of reform. }\end{array}$ & $\begin{array}{c}\text { Product innovation, proactiveness, taking a } \\
\text { tolerable risk }\end{array}$ \\
\hline Guth and Ginsberg [29]; Zahra [35] & $\begin{array}{l}\text { Stated as revitalizing an operating business } \\
\text { organization and reforming organizations by } \\
\text { reconstructing organizational concepts/ideas } \\
\text { at its commencement. }\end{array}$ & $\begin{array}{l}\text { Transformation and tactical revival of the } \\
\text { existing organization }\end{array}$ \\
\hline Cuervo et al. [27] & $\begin{array}{l}\text { It is a course of collaboration of people with a } \\
\text { firm in which other enterprises may evolve or } \\
\text { initiate the transformation of an existing } \\
\text { business. }\end{array}$ & $\begin{array}{l}\text { Corporate venture innovation and strategic } \\
\text { renewal }\end{array}$ \\
\hline J. G. Covin and M. P. Miles [36] & $\begin{array}{l}\text { CE is referred to as the skill of enterprises to } \\
\text { penetrate a niche market by providing and } \\
\text { adding new features to products and services } \\
\text { continuously. }\end{array}$ & $\begin{array}{c}\text { Sustained regeneration, organization } \\
\text { transformation, strategic renewal, and domain } \\
\text { redefinition }\end{array}$ \\
\hline Lumpkin and Dess [37] & $\begin{array}{c}\text { CE is all about the process of an organization } \\
\text { penetrating an already available or new } \\
\text { market by using differentiated products and } \\
\text { services. }\end{array}$ & $\begin{array}{c}\text { Innovation, assuming a calculable risk, } \\
\text { attentiveness }\end{array}$ \\
\hline $\begin{array}{l}\text { Hornsby et al. [38]; D.F. Kuratko et al. [39]; } \\
\text { Donald F. Kuratko et al. [40]; } \\
\text { Mcarthur et al. [41] }\end{array}$ & $\begin{array}{l}\text { Referred to as a general judgment for } \\
\text { introducing a novel concept to the } \\
\text { organization and putting it into action. }\end{array}$ & $\begin{array}{l}\text { Top-level administration endorses CE, } \\
\text { sufficient supply of input, organizational chart, } \\
\text { limit of structures }\end{array}$ \\
\hline $\begin{array}{c}\text { Donald F. Kuratko and Audretsch [20]; } \\
\text { Morris et al. [42] }\end{array}$ & $\begin{array}{l}\text { CE is a method by which an entrepreneur's } \\
\text { character influences the changes that happen } \\
\text { in an organization irrespective of company } \\
\text { strategy for reform. }\end{array}$ & $\begin{array}{l}\text { Organizational reform, entrepreneurial } \\
\text { strategy }\end{array}$ \\
\hline
\end{tabular}

Source: own compilation from Ravjee and Mamabolo [30].

\subsection{Innovativeness and Its Impact on Performance of Small and Medium Enterprises}

Innovativeness can be defined as a value-adding process to an organization, its providers, and consumers. The application of innovation in a business organization is very helpful to enhance organizational performance, economic growth, and social changes, where corporate entrepreneurship has the substantial effect of enhancing the impact of innovation on a firm's growth [43]. Moreover, Bigliardi [44] also confirmed that innovation 
has a transitory effect on firms to obtain a competitive advantage such as higher sales and growth.

Lwamba and Bwisa [45] explored the effect of innovation on the economic performance of industries in Kenya; their findings indicated that the relationship between economic performance and product or organizational innovativeness is positive and statistically significant. Moreover, researchers have argued that innovative businesses enjoy more success over others [46]. The study of Bartolacci et al. [47] also indicated that innovation has a great effect on the performance of enterprises by influencing each stage of operation (input, process, final product, or service), which can be considered as process, product, and market innovation.

Process innovation is a new organizational form of knowledge, policies, and procedures that is embodied in distribution applications, products, channels, and customers' needs, preferences, and expectations. It can be associated with an application of a significantly improved new delivery method and production system [48]. Lessening the cost of production, increasing the volume of production, and suppleness are some forms of measurement of organizational performance associated with process innovation as they focus on production [49]. It has also been stated that business firms use process innovation to tackle weaknesses in their internal capabilities that they acquire as embodied knowledge. In addition to this, Eiriz et al. [50] suggested that product innovation is associated with strategic determinants and is most important in the early phase of the life cycle. Moreover, Rouse et al. [51] contended that product innovation is about a firm's process of introducing new technology, new manufacturing methods, new commodities/products, new ideas, new delivery and distribution methods, and workflows. On the other hand, market innovation aims to ensure consumers' needs are met, in order to provide an organization with a new position in the market in efforts to increase the income from sales, and to open up new markets. Market innovation is associated with product offers, promotion activities, product placement, design properties, and pricing strategies [52]. Furthermore, organizational innovation refers to implementing new organizational approaches in an organization's business practices, external relations, and corporate organization [53]. Organizational innovations are meant to increase an organization's performance by reducing transaction, administrative, and supply costs, improving workplace satisfaction, and gaining access to non-tradable assets [54]. Innovative organizations, particularly those with a high innovativeness score for process, product, and organizational innovation, have higher total exports and sales [8]. In this regard, organizational innovation is more likely to lead to a reduction in administrative transaction costs, as well as enhancing satisfaction in the work environment [55]. Therefore, the authors posited the following hypothesis:

Hypothesis 1 (H1). Innovation has a statistically significant positive relationship with a firm's performance.

\subsection{Effect of Proactiveness on SMEs' Performance}

According to Saxena and Maru [56], firm growth refers to an increase in an organization's attributes including profits, employment, and sales between two periods in time. Firm growth is often determined by the capacity of the organization's capability and effectiveness with organization-specific resources, which include knowledge, capital, and labor, which are organized, acquired, and transformed into services and products that can be sold through organizational structures, routines, and practices. Ambad and Wahab [57] showed that the proactiveness dimension of corporate entrepreneurship has a negative relationship with firms' performance; however, it has a significant impact on organizational profitability.

Proactiveness can be seen as the style that an organization follows to make a decision, as well as a technique of using other features of entrepreneurial ability and approaches of an enterprise as a fundamental strategy for business sustainability [58]. This means proactiveness is a process of developing and introducing new products and services to the 
market and keeping their momentum by supporting them with research and developments of enterprises [59]. Companies that practice proactiveness behavior can easily detect strange movements in the market and take advantage of newly available opportunities. These companies then gain a first-mover advantage and can secure knowledge of key factors and issues and access to rare resources, carve out their market share, and place themselves in an advantageous position that will be costly for rivals to overtake [60]. The tendency of proactiveness is oriented towards achievement and anticipation, with emphasis on taking the initiative, predicting changes towards a significant situation, creating change, and early preparation for the occurrence of an impending uncertain risk [61]. SMEs that adopt proactiveness in their business can anticipate the demands and needs of the market and are therefore capable of anticipating the needs of consumers [62].

Fatoki [63] studied the entrepreneurial orientation of MSMEs in South Africa's retail sector and suggested that practicing the proactiveness dimension of $C E$ in small and medium enterprises is insignificant when compared to large organizations. Oni [64] conducted a study to examine the importance of the proactiveness of entrepreneurs as well as its effect on the performance of an enterprise, which revealed that enterprises that acted with high entrepreneurial proactiveness had a direct effect on the performance metrics that are consistent with the employment of competent and qualified personnel and size. Thus, we posited the second hypothesis, which is dependent on scholars' arguments, as follows:

Hypothesis 2 (H2). Proactiveness has a statistically significant positive relationship with a firm's performance.

\subsection{Effect of Risk Taking on SMEs' Performance}

Risk taking involves engagement in manageable and calculated risks in an attempt to achieve benefits, rather than taking daring risks that can negatively affect organizational performance. Y. Wang and Poutziouris [65] suggested that risk taking, as a firm-level strategic posture, constitutes a potential source for firms' sustainability by its long-term effect on financial performance, as well as growth. Risk taking was found to be dependent upon the size of the firm. Balabanis and Katsikea [66] argued that the size of the organization influences its risk-taking propensity. This is because access to a large pool of resources among larger organizations allows them to make risky decisions and spread them among several markets and products. Thus, it is expected that large firms have a high level of risk-taking propensity. The study of Balabanis and Katsikea [66] suggested that the association between risk taking and organizations' financial performance is positive and also statistically significant and finally concluded that risk taking is a major determinant of $\mathrm{CE}$ and financial performance in large businesses. However, most of the small and medium enterprise owners' / managers' opinions in Kenya showed that the risk taking dimension of corporate entrepreneurial also had an impact on the performance of SMEs [41]. The authors also indicated that risk taking and firms' performance have a positive relationship and are also statistically significant. Ključnikov et al. [67] examined the influence of competitive aggressiveness and risk taking in SME management and revealed that young firms had a greater willingness to invest in risky projects. In addition to this, the study of Anderson and Eshima [68] also confirmed that young organizations can take risks in the market. This is because younger firms can be more flexible in terms of taking risks as compared to older firms, which have a strategic direction.

Peng's [69] study on risk taking and firm growth found that risk taking has an economic and statistically significant impact on firm growth and earnings. There is also a positive relationship between risk taking and firm earnings, and therefore an organization with a higher level of risk taking has a small cash flow shortfall. On the other hand, the study of Togok et al. [70] suggested that large organizations can gain an advantage from the risk taking dimension of corporate entrepreneurship over small and medium enterprises due to their internal capacity to hold the risk. Therefore, we proposed the following third hypothesis for this study: 
Hypothesis 3 (H3). Risk taking has a statistically significant positive relationship with a firm's performance.

\subsection{Operationalizing the Study Variables}

- Organizational Performance: Most of the time, the measurement of firms' performance was indicated by the percentage of achieved objectives [71]. Above all, the performance of a business enterprise can be viewed as how much the firm meets the projected target of the company and fulfills the interests of major stakeholders [72]. In this regard, the business performance of SMEs can be taken as a foundation for the country's economy as well as sustainable development [73,74]. Therefore, we used sales volume, customer satisfaction, and profitability of the firm as a base for the performance measurements of SMEs.

- Innovativeness: In this study, innovativeness was measured by SMEs' broadening of new markets through new product expansions and embracing innovative work designs. SMEs regularly trial new techniques of manufacturing products and lead innovative distribution methods to markets, as well as innovative approaches of operation that minimize the time of production which leads to a decrease in costs, thereby realizing a profit margin. SMEs' organizational renovation helps to achieve operational efficiency and adopt innovative reward systems. Many SMEs have been known for their experiences with the innovation process. The innovative indicators used in this study are similar to those in [8,48-50].

- Proactiveness: Studies have shown that the tendency of proactiveness is oriented towards achievement and anticipation, with emphasis on taking the initiative, predicting changes towards a significant situation, creating change, and early preparation for the occurrence of an impending uncertain risk [57]. Thus, in this particular study, we measured proactiveness in terms of the tendency to be ahead of competitors; to be first in introducing new products or services, administrative techniques, and operating technologies; to lead customers rather than respond to their needs; to find the solution to unanticipated customer needs; and to determine extra needs of customers that they are not aware of.

- Risk Taking: Risk taking is not simply assuming a risk that affects organizational performance negatively; rather, it is about taking a risk that is manageable and that benefits the firm. Therefore, we used the tendency of the firm to invest in risky and new ideas/concepts.

Depending on the reviewed litreture, the following conceptual framework was developed as shown in the following Figure 1.

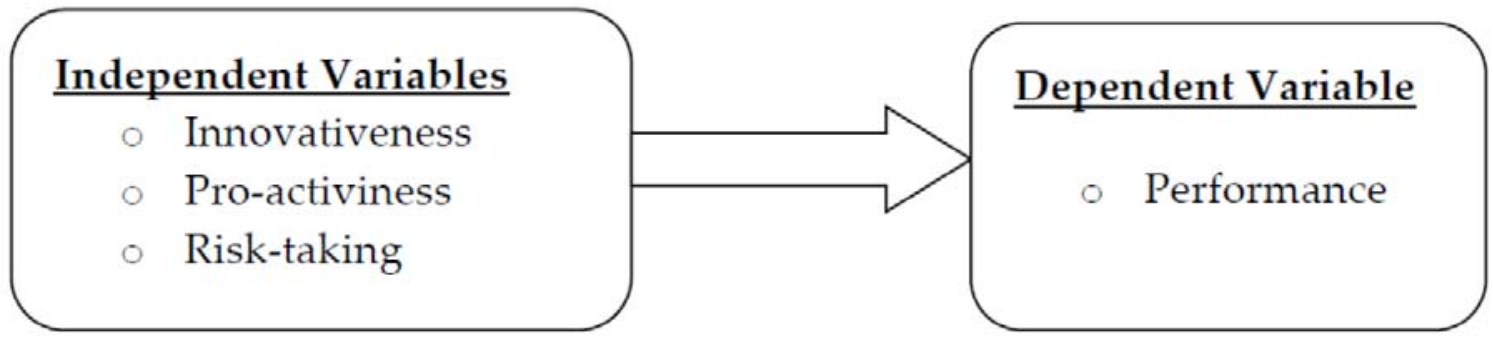

Figure 1. Conceptual framework of this study. Source: own compilation from related studies that were reviewed.

\section{Materials and Methods}

\subsection{Research Design}

Kothari [75] suggested that the research design expresses both the structure of the research problem, the framework, the organization, or the configuration of the relationships among variables of a study, and the plan of investigation used to obtain empirical evidence on those relationships. Accordingly, we used both descriptive and explanatory research 
designs to achieve the general objective of the study and to address the research questions. A descriptive research design was used to describe aspects of $C E$ practices that had been undertaken by SME owners and their implementation to improve the performance of the organization in terms of graphs, tables, frequencies, and percentages; meanwhile, an explanatory research design was used to inspect the effects of CE dimensions on SMEs' performance.

\subsection{Sampling Technique and Sample Size Determination}

Saunders et al. [76] and Naing [77] posited that a sampling frame has properties that allow the researcher to identify every single element and include any in the samples. Accordingly, we used probability sampling based on the stratified simple random sampling technique. This method was chosen because it obtains a sample population that best represents the entire population being studied. This technique reduces sample selection bias and therefore ensures that certain segments of the population are not underrepresented or overrepresented. In the sampling procedure, SMEs were stratified into four strata. This included the service sectors (117), manufacturing sectors (36), merchandising sectors (65), and construction sectors (87), as presented in Table 2.

Table 2. Study population and sample.

\begin{tabular}{ccc}
\hline Respondents' Sectors & Target Population & Sample Size \\
\hline Service sectors & 117 & 65 \\
\hline Manufacturing sectors & 36 & 24 \\
\hline Construction sectors & 87 & 46 \\
\hline Merchandising sectors & 65 & 38 \\
\hline Total & 305 & 173 \\
\hline
\end{tabular}

Source: own compilation.

To determine the sample size, this study adopted Yamane's [78] formula with a 95\% confidence level. This method was adopted since the population was known (finite), and because it allows for correction of the proportion. The calculation formula is shown below, where $\mathrm{e}=$ tolerance at the preferred level of confidence, $\mathrm{N}=$ study population, and $\mathrm{n}=$ sample size, with $\alpha=0.05$ at the $95 \%$ confidence level. The sample size for this study was established as 173 respondents.

$$
n=\frac{305}{1+305 \times(0.05)^{2}}=173
$$

Based on the above formula, we selected the following sample size from each of the sectors.

\subsection{Source of Data and Data Collection Instruments}

We used questionnaires as data collection instruments for our primary data source in addition to the secondary sources from manuals and company broachers. The questionnaire consisted of open- and closed-ended questions; we used Likert scale questions to design the questionnaire to indicate to what extent their firm adopted corporate entrepreneurship in their operations. The questionnaires were divided into 2 sections. Section 1 of the questionnaire aimed at collecting company information, whereas section 2 addressed responses regarding the impact of $\mathrm{CE}$ on small companies' performance.

\subsection{Reliability and Validity of the Instruments}

According to Kumar et al. [79], pilot studies are instrumental in the framing of questions, collection of background information, refinement of a research approach, or tailoring of efficient research instruments. Furthermore, Kothari [75] asserted that pretesting of 
questionnaires and interviews assist in identifying vague questions, obtaining suggestions, identifying deficiencies, and helping to identify suitable data analysis methods for the study. Therefore, the results from the pilot study enabled the authors to check and validate the research tools for the actual research. Accordingly, the authors discovered that the framed questionnaires had no doubts, which ensured that the results obtained in the pilot study were replicated consistently throughout the data collection.

Cronbach's alpha determines the internal consistency or average correlation of items in a survey instrument to gauge its reliability. Cronbach's alpha is an index of reliability that accounted for the true score of the underlying construct-the hypothetical variable that is being measured. The alpha coefficient ranges in value from 0 to 1 and is used to describe the reliability of factors extracted from dichotomous and/or multi-formatted questionnaires or scales. The higher the scale, the more reliable it can be regarded [80]. Therefore, the reliability of the questionnaire in this study was ascertained by Cronbach alpha statistics.

\subsection{Method of Data Analysis and Model Specification}

Data analysis is a process of examining, cleaning, converting, and analyzing data collected in the research. Means, standard deviations, frequencies, and percentages were employed in addition to the inferential statistics (correlations and regression) to measure the magnitude of impacts of explanatory variables on the explained variable and their relationships as well. Cohen [81] explained that correlation analysis is used to identify the relationship that exists among variables and its strength, which ranges from zero, denoting no association, to +1 , denoting a perfect association. A high index denotes a strong correlation between the study variables, whereas a low index denotes a weak correlation. Moreover, the general model used to measure the variability of performance of small and medium enterprises caused by CE dimensions is as follows:

SMEs Performance $=\alpha+\beta 1($ Innovativiness $)+\beta 2($ Proactiviness $)+\beta 3($ Risk taking $)+$ eit

Where: SMEs performance $=$ explained variable $\alpha=$ constant term; cit $=$ error terms; and $\beta 1-\beta 3$

$$
=\text { coefficients of independent variables }
$$

\section{Discussion and Analysis}

In this part of the study, we address the presentation, interpretation, and discussion of the main findings. From the empirical literature review of this study, it is possible to capture some of the magnitudes of CE such as innovativeness, proactiveness, and risk taking. This study took these magnitudes as variables and studied their effects on SMEs performances. Descriptive statistical analysis, such as percentages and frequencies, and means and standard deviations, was intended to present the general information about respondents and consistent CE dimensions in SMEs' performances. To evaluate the effects of CE on SMEs' performance, multiple linear regression was conducted. To this effect, 173 respondents participated, in which their responses are analyzed and discussed in the following section.

\subsection{Validity and Reliability}

We used Cronbach's alpha to quantify the reliability of values found from the instruments used during the data collection for every variable used in the study. The use of Cronbach's alpha is just to quantify respondents' opinions at a point to see if there is an inflated association between the items obtained [82]; it has been suggested that the approved value for alpha in social sciences is 0.7 . Thus, Table 3 confirms the validity and reliability of the items, as stated above. 
Table 3. Reliability and validity.

\begin{tabular}{ccc}
\hline Cronbach's Alpha Value & $\begin{array}{c}\text { Cronbach's Alpha Value Calculated } \\
\text { from Standardized Items }\end{array}$ & Number of Items (N) \\
\hline 0.9890 & 0.9920 & 25 \\
\hline Source: survey results of 2020. & &
\end{tabular}

The above Table 3 displays the reliability and validity of the variables, and accordingly, the Cronbach alpha value is 0.9890 , which is by far greater than 0.7000 . Thus, the data used for the variables (both the explained and the explanatory variables) are significant and also reliable.

\subsection{Respondents' Demographic Profile}

This subdivision encompasses parts that capture and summarize the demographic characteristics of the respondents in this study. The table below shows the frequency of the total respondents by their demographic information, and all 173 respondents were found to provide the information, with no missing values. The general information of respondents that were considered in this study was the respondents' gender, age, educational qualification, and experience in their business organizations. Each respondent's demographic information is discussed below.

Table 4 displays the demographic characteristics of the respondents, of which 102 (59\%) respondents were male and 71 (41\%) were female employees. This indicates that from the total participants of the survey, male respondents take the lion's share, implying that most SMEs in Holeta town were owned by males at the time of the study. Moreover, the age category shows that $67(38.7 \%)$ respondents were between 18 and 30 years old, $48(27.7 \%)$ respondents were between 31 and 40 years old, $33(19.1 \%)$ respondents were between 41 and 50 years old, and 25 (14.5\%) respondents were aged 51 years old and above. From this analysis, one can conclude that most SME owners, managers, and workers are in the productive age (18-30 years old), i.e., they are young and energetic.

Table 4. Respondents' demographic profile.

\begin{tabular}{|c|c|c|c|c|}
\hline \multicolumn{2}{|c|}{ Background Information of Participants } & \multirow{2}{*}{$\begin{array}{c}\text { Frequency } \\
102\end{array}$} & \multirow{2}{*}{$\begin{array}{c}\text { Percentage (out of 100) } \\
59\end{array}$} & \multirow{2}{*}{$\frac{\text { Cumulative Percent }}{59}$} \\
\hline \multirow{3}{*}{ Gender } & Male & & & \\
\hline & Female & 71 & 41 & 100 \\
\hline & Total & 173 & 100 & \\
\hline \multirow{5}{*}{ Age } & $18-30$ & 67 & 38.7 & 38.7 \\
\hline & $31-40$ & 48 & 27.7 & 66.5 \\
\hline & $41-50$ & 33 & 19.1 & 85.5 \\
\hline & Above 51 & 25 & 14.5 & 100 \\
\hline & Total & 173 & 100 & \\
\hline \multirow{4}{*}{ Education level } & Diploma & 77 & 44.5 & 44.5 \\
\hline & First degree & 62 & 35.8 & 80.3 \\
\hline & Above degree & 34 & 19.7 & 100 \\
\hline & Total & 173 & 100 & \\
\hline \multirow{5}{*}{ Work experience } & No experience & 52 & 30.1 & 30.1 \\
\hline & $1-5 y$ & 62 & 35.8 & 65.9 \\
\hline & $5-10 y$ & 36 & 20.8 & 86.7 \\
\hline & $>10 y$ & 23 & 13.3 & 100 \\
\hline & Total & 173 & 100 & \\
\hline
\end{tabular}


Concerning the educational level of the respondents, the information in the above table reveals that about $77(44.5 \%)$ employees were diploma holders, 62 (35.8\%) were first degree holders, and the remaining $47(24 \%)$ respondents had a master's degree or above. The findings imply that most of the respondents had a high level of education which could have contributed to obtaining accurate responses from the participants.

Respondents were also asked to indicate their work experience in their current organization. As the result shows in Table 4, 52 (30.1\%) employees had no experience in conducting business, 62 (35.8\%) employees had served for 1-5 years, 36 (20.8\%) employees had served between 5 and 10 years, and $23(13.3 \%)$ respondents had worked more than 10 years. From this, we conclude that most respondents had 1-5 years of work experience. This result indicates that almost all of the respondents had sound knowledge and experience in their business, meaning that they provided reliable information in the research questionnaires.

\subsection{SMEs' Background Information}

This subdivision encompasses parts that capture and summarize SMEs' background information for this study. The table below shows the frequency of total respondents by their SMEs' background information. The general information of respondents that were considered in this study was the organizational duration, sector category, number of employees in the business organizations, and annual sales. Each SME's information is discussed below.

Table 5 displays the background information of SMEs in the study area, and it shows that $73(42.2 \%)$ were $1-3$ years old, $55(31.8 \%)$ were $4-5$ years old, $30(17.3 \%)$ were $6-10$ years old, and $15(8.7 \%)$ were more than 10 years old. This indicates that most of the SMEs included in this study have been operating for more than one year, which is considered long enough to have appropriate knowledge about the issues the researchers were interested in. The results in Table 5 also show that $47(27.2 \%)$ SMEs were in construction sectors, $62(35.8 \%)$ SMEs were in service sectors, 35 (20.2\%) SMEs were in merchandising sectors, and $29(16.8 \%)$ SMEs were in manufacturing sectors. From this result, one can find that SMEs in Holeta town mainly operate in service sectors.

Relating to the number of employees of SMEs, the information in the above table reveals that about 51 (29.5\%) had 1-2 employees, 81 (46.8\%) had 3-10 employees, 23 (13.3\%) had 11-30 employees, and the remaining $18(10.4 \%)$ had more than 31 employees. This implies that the majority of SMEs in the town have 3-10 employees, which means that most SMEs in Holeta town perform business activities with limited employees.

As the result shows in the above table, 83 (48\%) SMEs gained ETB100,000, $23(13.3 \%)$ SMEs gained ETB 100,000-3,000,000, 15 (8.7\%) SMEs gained ETB 3,000,000-15,000,000, and $52(30.1 \%)$ SMEs had no response about their annual sales. This indicates that the majority of SMEs in Holeta town did not provide responses about their annual income. This implies there are some factors that respondents need to hide, and that further study could be undertaken on the issue. 
Table 5. SMEs' background information.

\begin{tabular}{|c|c|c|c|c|}
\hline \multicolumn{2}{|c|}{ SMEs' Information } & Frequency & Percent & $\begin{array}{c}\text { Cumulative } \\
\text { Percent }\end{array}$ \\
\hline \multirow{5}{*}{ Company Age } & $1-3$ years & 73 & 42.2 & 42.2 \\
\hline & $4-5$ years & 55 & 31.8 & 74 \\
\hline & $6-10$ years & 30 & 17.3 & 91.3 \\
\hline & More than 10 years & 15 & 8.7 & 100 \\
\hline & Total & 173 & 100 & \\
\hline \multirow{5}{*}{ Sector Category } & Construction sectors & 47 & 27.2 & 27.2 \\
\hline & Service sectors & 62 & 35.8 & 63 \\
\hline & Merchandising sectors & 35 & 20.2 & 83.2 \\
\hline & Manufacturing sectors & 29 & 16.8 & 100 \\
\hline & Total & 173 & 100 & \\
\hline \multirow{5}{*}{ Number of Employees } & $1-2$ & 51 & 29.5 & 29.5 \\
\hline & $3-10$ & 81 & 46.8 & 76.3 \\
\hline & $11-30$ & 23 & 13.3 & 89.6 \\
\hline & $31+$ & 18 & 10.4 & 100 \\
\hline & Total & 173 & 100 & \\
\hline \multirow{5}{*}{ Annual Sales } & $\leq$ ETB 100,000 & 83 & 48 & 48 \\
\hline & ETB100,000-ETB 3,000,000 & 23 & 13.3 & 61.3 \\
\hline & ЕТВ 3,000,000-ETB 15,000,000 & 15 & 8.7 & 69.9 \\
\hline & No response & 52 & 30.1 & 100 \\
\hline & Total & 173 & 100 & \\
\hline
\end{tabular}

Source: own compilation from study results.

\subsection{Descriptive Analysis of CE on Performances of SMEs}

In Table 6, it can be observed that the overall average mean is 3.61. Therefore, it can be suggested that the risk-taking behaviors of an entrepreneur or SME owner have a significant impact on their business performance. However, innovativeness and proactiveness also have a positive significant effect, as shown by the standard deviations of 1.06 and 1.13 , respectively, which are above the average standard deviation of 1.01. These results are also supported by the interviews, where participants were asked to elaborate on how they understood the term corporate entrepreneurship. In the interview participants' opinions, various responses were verified; accordingly, business ventures could be considered as identifying opportunities, and solutions to current problems, networking, new business ideas, risk taking, and innovation. All these ideas came from different respondents; however, the challenge was to elucidate whether CE is being executed in SMEs.

Table 6. Descriptive analysis of CE.

\begin{tabular}{cccc}
\hline & $\mathbf{N}$ & Mean & Standard Deviation \\
\hline Innovativeness & 173 & 3.25 & 1.06 \\
\hline Proactiveness & 173 & 3.20 & 1.13 \\
\hline Risk taking & 173 & 3.61 & 0.85 \\
\hline Valid N (listwise) & 173 & & \\
\hline Average mean $=3.35$. Average standard deviation $=1.01$. Source: survey results of 2020.
\end{tabular}

Average mean $=3.35$. Average standard deviation $=1.01$. Source: survey results of 2020 . 


\subsection{Results of Inferential Statistics}

Correlations

The correlations of variables quantify the associations between them. To examine the extent of the effects of CE activities on the performance of SMEs, the Pearson correlation coefficient was calculated. According to Galkina and Chetty [83], the linearity of the relationship among variables is measured by Pearson correlation coefficients, that is, if one variable increases or decreases, what is the extent to which other variables increase or decrease. In analyzing the data, the researchers used correlation analysis, which is used to test for the strength of the relationships between CE dimensions and the performance of SMEs. Correlations can vary between +1 and -1 , where 1 is a perfect positive correlation, and -1 is a perfect negative correlation. The squared correlation is the measure of the strength of the association [84]. Table 7 below clearly describes the correlation coefficient guidelines and ranges of coefficient values to predict the strength of relationships.

Table 7. Correlation coefficient guidelines.

\begin{tabular}{cc}
\hline Correlation Coefficient (r) & Strength of the Correlation \\
\hline 0.50 to 1.0 or -0.50 to -0.10 & Strong relationship \\
\hline 0.30 to 0.49 or -0.30 to -0.49 & Moderate relationship \\
\hline 0.10 to 0.29 or -0.10 to -0.29 & Weak relationship \\
\hline
\end{tabular}

Source: Cohen [75].

To minimize the confusion of $\mathrm{r}$ values in Table 7 , i.e., to show the similarity and difference of the positive and negative values of the correlation coefficient (r), the interpretation of the values is one and the same, except their direction (in the opposite or same direction).

Table 8 illustrates the correlations between independent and dependent variables. Accordingly, all the explanatory variables have a positive and strong relationship with the explained variable, i.e., $r=0.917,0.909$, and 0.913 for innovativeness, proactiveness, and risk taking with SMEs' performance, respectively, all at $p<0.005$. This implies that innovativeness activities, which are significant at $p<0.05$, contribute 0.917 (97.5\%) to the performances of SMEs. Proactiveness activities, which are significant at $p<0.05$, contribute $0.909(90.9 \%)$ to the performances of SMEs. Lastly, risk taking, which is significant at $p<0.05$, contributes 0.913 (91.3\%). Therefore, according to the interpretation of the size of the coefficient by Cohen [81], $\mathrm{CE}$ contributes to the performances of SMEs in economic conditions to a great extent. Therefore, this study accepts the alternate/H1 Hypothesis which is as follows: CE contributes to the performances of SMEs. The results support the findings of Kwinje et al. [11] and Etim et al. [85], who found that CE variables (innovation, proactiveness, and risk taking) had a significant positive influence on SMEs' performances.

Table 9 depicts a summary of the model used in this particular study. Adjusted $\mathrm{R}$-square is more preferable to R-square to decide the goodness of the linear regression model [84]. From this summary, the value of adjusted R-square was 0.853 , which indicates that more than $85 \%$ of the variability in the dependent variable (SMEs' performance) was explained by the explanatory variables (innovativeness, reactiveness, and risk taking), and the remaining $14.7 \%$ accounted for the variables which were not included in this study. Another very important value from the summary table is a section that indicates the significance of the variables, i.e., $p=0.000$ indicates that all the variables are statistically significant at the $1 \%$ significance level. Therefore, we concluded that all the variables selected for the study were a good predictor for the performance of small and medium enterprises. 
Table 8. Table of correlations.

\begin{tabular}{|c|c|c|c|c|c|}
\hline \multicolumn{6}{|c|}{ Correlations } \\
\hline & & SMEs' Performance & Innovativeness & Proactiveness & Risk Taking \\
\hline \multirow{3}{*}{ SMEs' Performance } & Pearson Correlation & 1 & $0.917^{* *}$ & $0.909 * *$ & $0.913^{* *}$ \\
\hline & Sig. (2-tailed) & & 0.000 & 0.000 & 0.000 \\
\hline & $\mathrm{N}$ & 173 & 173 & 173 & 173 \\
\hline \multirow{3}{*}{ Innovativeness } & Pearson Correlation & $0.917^{* *}$ & 1 & $0.968 * *$ & $0.968^{* *}$ \\
\hline & Sig. (2-tailed) & 0.000 & & 0.000 & 0.000 \\
\hline & $\mathrm{N}$ & 173 & 173 & 173 & 173 \\
\hline \multirow{3}{*}{ Proactiveness } & Pearson Correlation & $0.909 * *$ & $0.968^{* *}$ & 1 & $0.950 * *$ \\
\hline & Sig. (2-tailed) & 0.000 & 0.000 & & 0.000 \\
\hline & $\mathrm{N}$ & 173 & 173 & 173 & 173 \\
\hline \multirow{3}{*}{ Risk Taking } & Pearson Correlation & 0.913 ** & $0.968^{* *}$ & $0.950 * *$ & 1 \\
\hline & Sig. (2-tailed) & 0.000 & 0.000 & 0.000 & \\
\hline & $\mathrm{N}$ & 173 & 173 & 173 & 173 \\
\hline
\end{tabular}

** Significant at $99 \%$ confidence level. Source: study results of 2020.

Table 9. Summary of model used.

\begin{tabular}{|c|c|c|c|c|c|c|c|c|c|c|}
\hline \multicolumn{11}{|c|}{ Summary ${ }^{b}$. } \\
\hline \multirow[b]{2}{*}{ Model } & \multirow[b]{2}{*}{$\mathbf{R}$} & \multirow[b]{2}{*}{$\mathbf{R}^{2}$} & \multirow[b]{2}{*}{ Adjusted $\mathbf{R}^{2}$} & \multirow{2}{*}{$\begin{array}{l}\text { Std. Error } \\
\text { of the } \\
\text { Estimate }\end{array}$} & \multicolumn{5}{|c|}{ Change Statistics } & \multirow{2}{*}{$\begin{array}{l}\text { Durbin- } \\
\text { Watson }\end{array}$} \\
\hline & & & & & $\begin{array}{l}\text { R-Square } \\
\text { Change }\end{array}$ & F Change & df1 & df 2 & $\begin{array}{c}\text { Sig. F } \\
\text { Change }\end{array}$ & \\
\hline 1 & $0.925^{\mathrm{a}}$ & 0.855 & 0.853 & 0.25645 & 0.855 & 332.680 & 3 & 169 & 0.000 & 0.062 \\
\hline
\end{tabular}

The analysis of variance (ANOVA) provided statistics about the overall significance or fitness of the model used. The significance value $p=0.000$ indicates that the overall fitness of the model is perfect to predict the values of the variables. From the ANOVA (analysis of variance) in the Table 10 shown above, it is possible to see that, from the total observation value (76.753), the regression model explains the majority of the observation (65.639). The remaining (11.115) is not explained by the model. Hence, it is possible to deduce that the regression explains most of the observations, while the other observations are explained by extraneous variables.

Table 10. Test for model fitness.

\begin{tabular}{|c|c|c|c|c|c|c|}
\hline \multicolumn{7}{|c|}{ ANOVA $^{a}$} \\
\hline \multicolumn{2}{|c|}{ Model } & Sum of Squares & Df & Mean Square & $\mathbf{F}$ & Sig. \\
\hline \multirow{3}{*}{1} & Regression & 65.639 & 3 & 21.880 & 332.680 & $0.000^{b}$ \\
\hline & Residual & 11.115 & 169 & 0.066 & & \\
\hline & Total & 76.753 & 172 & & & \\
\hline
\end{tabular}

${ }^{a}$ Dependent variable: performance of SMEs; ${ }^{b}$ predictor (constant value): risk taking, proactiveness, innovativeness. Source: from SPSS output.

Table 11 displays the coefficients of each variable, that is, the beta values in the model. Accordingly, the beta value of the innovativeness dimension equals 0.199 , that of the provocativeness dimension is 0.165 , and that of the risk taking dimension is 0.269 . Therefore, for a certain variation in each independent variable as stated above, there was a consistent variation in the performance of SMEs. That is, the innovativeness dimension predicted the performance of SMEs at $19.9 \%$, the proactiveness dimension predicted the performance of SMEs at $16.5 \%$, and the risk taking dimensions predicted the performance 
of SMEs at $26.9 \%$, in the same direction. This means that when the value of innovativeness, proactiveness, and risk taking is increased or decreased by one unit, the value of SMEs' performance varies by $0.199,0.165$, and 0.269 , respectively, in the same direction. To make it clearer, consider the following equation which was proposed for this study in the above section:

SMEs' Performance $=2.233+0.199$ (Innovativeness $)+0.165$ (Proactiveness $)+0.269($ Risk Taking $)+$ the Error Terms

Table 11. Table coefficients.

\begin{tabular}{|c|c|c|c|c|c|c|c|c|}
\hline \multicolumn{9}{|c|}{ Coefficients } \\
\hline & \multirow{2}{*}{ Model } & \multicolumn{2}{|c|}{ Unstandardized Coefficients } & \multirow{2}{*}{$\begin{array}{c}\begin{array}{c}\text { Standardized } \\
\text { Coefficients }\end{array} \\
\text { Beta }\end{array}$} & \multirow{2}{*}{$\mathrm{T}$} & \multirow{2}{*}{ Sig. } & \multicolumn{2}{|c|}{$\begin{array}{l}95.0 \% \text { Confidence Interval } \\
\text { for } \mathrm{B}\end{array}$} \\
\hline & & B & Std. Error & & & & $\begin{array}{l}\text { Lower } \\
\text { Bound }\end{array}$ & $\begin{array}{l}\text { Upper } \\
\text { Bound }\end{array}$ \\
\hline \multirow{4}{*}{1} & (Constant) & 2.233 & 0.123 & & 18.086 & 0.000 & 1.989 & 2.476 \\
\hline & Innovativeness & 0.199 & 0.093 & 0.316 & 2.150 & 0.033 & 0.016 & 0.382 \\
\hline & Proactiveness & 0.165 & 0.070 & 0.280 & 2.355 & 0.020 & 0.027 & 0.304 \\
\hline & Risk taking & 0.269 & 0.094 & 0.341 & 2.864 & 0.005 & 0.084 & 0.454 \\
\hline
\end{tabular}

Source: survey results of 2020 .

Table 11 further shows that the explanatory variables explained the variation in the dependent variable at a 95\% confidence level. In other words, a unit intervention by the risk taking dimension can enhance the growth of SMEs by $34.1 \%$, other things remaining constant, and also a unit intervention by the innovativeness dimension can enhance (affect) the performance of SMEs by 31.6\%, other things being held constant.

Table 12 depicts the justification of the hypotheses developed for this particular study, which were based on the findings of previous works, which can be summarized as follows:

Table 12. Hypothesis justification.

\begin{tabular}{lcc}
\hline \multicolumn{1}{c}{ Particulars } & Beta & Sig. \\
\hline $\begin{array}{l}\text { Hypothesis 1. Innovation has a positive relationship with firms' } \\
\text { performance and is statistically significant. }\end{array}$ & 0.199 & 0.033 \\
\hline $\begin{array}{l}\text { Hypothesis 2. The proactiveness dimension of corporate } \\
\text { entrepreneurship has a positive relationship with firms' performance and } \\
\text { is statistically significant. }\end{array}$ & 0.165 & 0.020 \\
\hline $\begin{array}{l}\text { Hypothesis 3. Risk taking has a positive relationship with firms' } \\
\text { performance and is statistically significant. }\end{array}$ & 0.269 & 0.005
\end{tabular}

Source: survey results of 2020 .

Hypothesis 1. The innovativeness dimension of CE has a positive relationship with firms' performance (here, the beta value is positive, equaling 0.199, and is statistically significant ( $p$-value is less than 0.05, $p=0.033)$ ). Therefore, it is concluded that the proposed Hypothesis (H1) is supported by the research results. These results are supported by a study conducted in Ghana [86] which found a significant positive relationship between innovation, proactiveness, and profitability. Additionally, in their study of 94 Turkish manufacturing foreign direct investment (FDI) firms, [87] found that two dimensions of entrepreneurial orientation, innovation and proactiveness, positively and significantly affected the performance of the firms.

Hypothesis 2. The proactiveness dimension of CE has a positive relationship with firms' performance, i.e., the beta value is positive, equaling 0.165, and statistically significant ( $p$-value is less than $0.05, p=0.020$ ). Thus, we conclude that the proposed Hypothesis (H2) is supported by the research outcomes. This result is also supported by the study of [88] using survey data gathered from 164 Dutch SMEs, which showed that proactive firm behavior positively contributed to SMEs' 
performance during economic catastrophes. This result is also supported by the study of [89] who studied small businesses in South Africa and found that proactiveness and innovativeness had a significant positive influence on the success of small businesses.

Hypothesis 3. The risk taking dimension of CE has a positive relationship with firms' performance, i.e., the beta value is positive, equaling 0.269 , and statistically significant ( $p$-value is less than 0.05 , $p=0.005$ ). Therefore, it can be concluded that the proposed Hypothesis (H2) is supported by the research findings.

\subsection{Discussion of Major Results}

This section outlines the major findings of this study in a comprehensive form which was backed up by previous research. Accordingly, the mean and standard deviation of the innovativeness dimension of $\mathrm{CE}$ in the above section were shown to be 3.25 and 1.06 , respectively. Hence, from this descriptive statistic, we can observe that the participants assured the variable had an impact on the smooth operation of the enterprises and their performance. Moreover, there is a strong association between innovativeness and firms ${ }^{\prime}$ performance, which is also statistically significant, with the values of $r=0.917$, beta $=0.199$, and $p<0.05$, which means that increasing or decreasing the activity of innovativeness by one unit or percent will result in an increment or decrement in the performance of the firm by $19.9 \%$. Similar results were obtained by prior research work of several authors [90-93]. In addition to this, Luo et al. [94] indicated that in today's stiff firm competition, the ability of entrepreneurs, managers, and business owners to innovate new products, processes, or marketing techniques has a great role in their enterprises' performance as they take market opportunities.

Regarding the second variable of this study, i.e., proactiveness, the mean and its standard deviation from the results of the descriptive statistics were 3.20 and 1.13, respectively. This indicates that more than an average number of respondents confirmed that the variable has an impact on the performance of their enterprises. In addition to this, the correlation and regression results of this study indicate that there is a positive and strong relationship between proactiveness and the performance of enterprises, with the values of $\mathrm{r}=0.909$ and beta $=0.165$, which is also statistically significant, i.e., its $p$-value is less than 0.05 . From these statistical values, we can deduce that as the value of proactiveness increases or decreases by one unit or percent, the performance of enterprises can increase or decrease in the same direction by $16.5 \%$ or units. The capacity of a manager to scan business environments and their ability to find a proactive solution before the problem is encountered have a paramount effect on an enterprise's performance [60]. Thus, the results of the current study are also supported by previous research works in the field.

Risk taking is the third explanatory variable of this study, and its mean and standard deviation results were 3.61 and 0.85 , respectively. This statistical result indicates that an above average number of the respondents suggested the variable has an impact on the performance of their enterprises. Moreover, the correlation and regression results of the study indicate that there is a positive and strong relationship between risk taking and the performance of enterprises, with values of $r=0.913$ and beta $=0.269$, which is also statistically significant, i.e., its $p$-value is less than 0.05 . This result is also supported by Semrau et al. [95], and Tang and Tang [96], as they suggested that risk taking has a positive result on the performance of an enterprise by its lucrative returns on their investments.

\section{Conclusions}

As elaborated on and analyzed in different sections of this paper, the main objective of this study was to evaluate the degree of contributions of corporate entrepreneurship dimensions to the performance of small and medium enterprises. Thus, this study laid some foundations for SME owners and managers to revisit their capacity and ability to implement $\mathrm{CE}$ activities in their business operation to cope with the global competition. It is a fact that globalization dictates organizations in pursuing new technologies, production 
systems, and methods of decision making, as the business environment can be considered a single village where many rival firms compete for the market in one battle [97]. In this regard, managers need to be innovative, proactive, and decisive decision makers and accept tolerable and calculable risks to exploit the market opportunities ahead of competitors. One can take away several implications of the impacts of dimensions of corporate entrepreneurship on firms' performance from this particular study. Among other things, innovativeness, proactiveness, and risk taking are significant components of firms' performance, which all employees of an organization need to be aware of. The findings of this particular study are supported by several previous research works in the field $[1,2,98,99]$. Finally, business owners and managers have to create a conducive environment for key stakeholders of their business, mainly employees, to make the concept of corporate entrepreneurship their organizational culture.

\section{Implications}

Innovation is a key factor for the success of many businesses. As businesses seek to improve their productivity and ensure sustained growth, they will need to improve their capacity to innovate. Therefore, it would be worthwhile to note additional corporate entrepreneurship strategies, as such strategies may not only benefit a firm's internal innovation performance but also advance the firm's productivity, marketability, and competitive advantage.

\section{Limitations and Future Suggestions}

The focus of this study was only the effects of CE on SMEs in Holeta town, Ethiopia. Hence, the results, therefore, are limited in terms of generalizations and therefore are not a complete representation of all SMEs in Ethiopia. In particular, this study did not consider all small business enterprises, including those that are not legally registered. Therefore, future research should also verify the factors affecting the implementation of $\mathrm{CE}$ and directions of $C E$ strategic approaches, as there may be discrepancies between various corporations or industries. Additionally, this study only used questionnaires and interview methods for data collection. Hence, future investigations could examine the outcomes posed in the strategic framework by using an additional method such as observation and focused group discussion, since different effects could result from a specific SME. Finally, this research only focused on the corporate entrepreneurship dimensions of proactiveness, innovation, and risk taking. Hence, it is recommended that future researchers add self-renewal as part of the corporate entrepreneurship dimensions.

Author Contributions: Supervision: C.B.I.; comments on the manuscript at all stages: C.B.I. and A.D.; conceptualization: G.A., A.A. and A.D.; design: G.A. and A.A.; data acquisition: A.A.; analyzing and interpreting the data: A.A. and G.A.; writing the original draft: A.A. and G.A.; final review: C.B.I. and A.D. All authors have read and agreed to the published version of the manuscript.

Funding: There was no external funding source for this study.

Institutional Review Board Statement: Not applicable.

Informed Consent Statement: Not applicable.

Data Availability Statement: Not applicable.

Acknowledgments: We would like to provide heartfelt gratitude to all who contributed in one way or another to bringing this article up to this level. Our respondents, the business owners and managers of SMEs in Holeta town, and government officials deserve special thanks from us.

Conflicts of Interest: We declare that there is no conflict of interest among us.

\section{References}

1. Wahyudi, I.; Suroso, A.I.; Arifin, B.; Syarief, R.; Rusli, M.S. multidimensional aspect of corporate entrepreneurship in family business and SMEs: A systematic literature review. Economies 2021, 9, 156. [CrossRef] 
2. Kreiser, P.M.; Kuratko, D.F.; Covin, J.G.; Ireland, R.D.; Hornsby, J.S. Corporate entrepreneurship strategy: Extending our knowledge boundaries through configuration theory. Small Bus. Econ. 2021, 56, 739-758. [CrossRef]

3. Oliver, K. Exploring the Nature and Extent of Entrepreneurial Intensity in the Insurance Industry in Hyper-Inflationary Zimbabwe 2007-2010. Ph.D. Dissertation, University of Pretoria, Pretoria, South Africa, 2017.

4. Zehir, C.; Can, E.; Karaboga, T. Linking entrepreneurial orientation to firm performance: The role of differentiation strategy and innovation performance. Procedia-Soc. Behav. Sci. 2015, 210, 358-367. [CrossRef]

5. Parker, S.C. Intrapreneurship or entrepreneurship? J. Bus. Ventur. 2011, 26, 19-34. [CrossRef]

6. Kelley, D. Sustainable corporate entrepreneurship: Evolving and connecting with the organization. Bus. Horiz. 2011, 54, 73-83. [CrossRef]

7. Karacaoğlu, K.; Bayrakdaroglu, A.; San, F.B. The impact of corporate entrepreneurship on firms' financial performance: Evidence from istanbul stock exchange firms. Int. Bus. Res. 2012, 6, 163. [CrossRef]

8. Kuratko, D.F.; Hornsby, J.; Hayton, J. Corporate entrepreneurship: The innovative challenge for a new global economic reality. Small Bus. Econ. 2015, 45, 245-253. [CrossRef]

9. Antoncic, B.; Hisrich, R.D. Clarifying the intrapreneurship concept. J. Small Bus. Enterp. Dev. 2003, 10, 7-24. [CrossRef]

10. Kahkha, A.O.; Kahrazeh, A.; Armesh, H. Corporate entrepreneurship and firm performance important role of small and medium enterprise. Int. J. Acad. Res. Bus. Soc. Sci. 2014, 4, 8-25. [CrossRef]

11. Bojica, A.M.; Fuentes, M.D.M.; Gómez-Gras, J.M. Radical and incremental entrepreneurial orientation: The effect of knowledge acquisition. J. Manag. Organ. 2011, 17, 326-343. [CrossRef]

12. Catherine, K.; Mwando, G.M.; Zengeni, N. Corporate entrepreneurship strategy and the survival of small to medium tourism enterprises in Zimbabwe. Afr. J. Hosp. Tour. Leis. 2020, 9, 732-746. [CrossRef]

13. Osman, M.; Ramayah, T.; Puspowarsito, H.; Natalisa, D.; Saerang, D.P.E. Corporate entrepreneurship and firm performance: The role of business environment as a moderator. IUP J. Manag. Res. 2011, 10, 7-27.

14. Gemechu, A.; Fitwi, T. Factors affecting performance of micro and small enterprises in South West Ethiopia: The case of Bench Maji, Sheka, and Kefa zones. Glob. J. Manag. Bus. Res. 2016, 16, 47-64.

15. Dunay, A.; Ayalew, A.; Abdissa, G. Why socially responsible? determinant factors of organizational performance: Case of dangote cement factory in Ethiopia. Sustainability 2021, 13, 4783. [CrossRef]

16. Umrani, W.A.; Mahmood, R.; Ahmed, U. Unveiling the direct effect of corporate entrepreneurship's dimensions on the Business Performance: A case of big five banks in Pakistan. Stud. Bus. Econ. 2016, 11, 181-195. [CrossRef]

17. Prasanna, R.; Jayasundara, J.; Gamage, S.K.N.; Ekanayake, E.; Rajapakshe, P.; Abeyrathne, G. Sustainability of SMEs in the competition: A systemic review on technological challenges and SME performance. J. Open Innov. Technol. Mark. Complex. 2019, 5, 100. [CrossRef]

18. Garcia-Torres, S.; Rey-Garcia, M.; Albareda-Vivo, L. Effective disclosure in the fast-fashion industry: From sustainability reporting to action. Sustainability 2017, 9, 2256. [CrossRef]

19. Chang, D.-S.; Chen, S.-H.; Hsu, C.-W.; Hu, A.H. Identifying strategic factors of the implantation csr in the airline industry: The case of Asia-pacific airlines. Sustainability 2015, 7, 7762-7783. [CrossRef]

20. Batista, A.A.D.S.; de Francisco, A.C. Organizational sustainability practices: A study of the firms listed by the corporate sustainability index. Sustainability 2018, 10, 226. [CrossRef]

21. Arruda, L.R.; Lameira, V.D.J.; Quelhas, O.L.G.; Pereira, F.N. Sustainability in the Brazilian heavy construction industry: An analysis of organizational practices. Sustainability 2013, 5, 4312-4328. [CrossRef]

22. Sarango-Lalangui, P.; Álvarez-García, J.; Río-Rama, M.D.L.C.D. Sustainable practices in small and medium-sized enterprises in ecuador. Sustainability 2018, 10, 2105. [CrossRef]

23. Amare, A.E.; Raghurama, A. Micro, small and medium enterprises (MSMEs) development strategies in Ethiopia: Retrospective and prospective analysis. Int. J. Commer. Bus. Manag. 2017, 6, 11-20.

24. Kuratko, D.F.; Audretsch, D.B. Clarifying the domains of corporate entrepreneurship. Int. Entrep. Manag. J. 2013, 9, 323-335. [CrossRef]

25. Kuratko, D.F.; Hoskinson, S. Introduction: The challenges of corporate entrepreneurship in the disruptive age. Adv. Study Entrep. Innov. Econ. Growth 2018, 28, 1-9. [CrossRef]

26. Sharma, P.; Chrisman, S.J.J. Toward a Reconciliation of the Definitional Issues in the Field of Corporate Entrepreneurship. In Entrepreneurship; Springer: Berlin/Heidelberg, Germany, 2007; pp. 83-103.

27. Álvaro, C.; Ribeiro, D.; Roig, S. Entrepreneurship: Concepts, Theory and Perspective; Springer: Berlin/Heidelberg, Germany, 2007; pp. 1-348. [CrossRef]

28. Kuratko, D.F.; Ireland, R.D.; Covin, J.G.; Hornsby, J.S.; Utsch, A.; Rauch, A.; Frese, M. A model of middle-level managersâ€ ${ }^{\mathrm{TM}}$ entrepreneurial behavior. Entrep. Theory Pract. 2005, 29, 699-716. [CrossRef]

29. William, D.G.; Ginsberg, A. Guest editors' introduction: Corporate entrepreneurship. Strateg. Manag. J. 1990, 11, 5-15.

30. Ravjee, B.; Mamabolo, M.A. The impact of corporate entrepreneurship on service innovation: A case of a South African banking institution. S. Afr. J. Entrep. Small Bus. Manag. 2019, 11, a155. [CrossRef]

31. Kuratko, D.F.; Covin, J.G.; Garrett, R.P. Corporate venturing: Insights from actual performance. Bus. Horiz. 2009, 52, $459-467$. [CrossRef] 
32. Hornsby, J.; Kuratko, D.F.; Shepherd, D.A.; Bott, J.P. Managers' corporate entrepreneurial actions: Examining perception and position. J. Bus. Ventur. 2009, 24, 236-247. [CrossRef]

33. Eric-Nielsen, J. Corporate entrepreneurship, organizational learning and knowledge implementation. Ekon. Horiz. 2015, 17, 203-217. [CrossRef]

34. Morris, M.H.; Paul, G.W. The relationship between entrepreneurship and marketing in established firms. J. Bus. Ventur. 1987, 2, 247-259. [CrossRef]

35. Zahra, S.A. Environment, corporate entrepreneurship, and financial performance: A taxonomic approach. J. Bus. Ventur. 1993, 8, 319-340. [CrossRef]

36. Covin, J.G.; Miles, M. Corporate entrepreneurship and the pursuit of competitive advantage. Entrep. Theory Pract. 1999, $23,47-63$. [CrossRef]

37. Lumpkin, G.T.; Dess, G.G. Clarifying the entrepreneurial orientation construct and linking it to performance. Acad. Manag. Rev. 1996, 21, 135-172. [CrossRef]

38. Hornsby, J.S.; Kuratko, D.F.; Montagno, R.V. Perception of internal factors for corporate entrepreneurship: A comparison of Canadian and U.S. managers. Entrep. Theory Pract. 1999, 24, 9-24. [CrossRef]

39. Kuratko, D.F.; Hornsby, J.; Covin, J.G. Diagnosing a firm's internal environment for corporate entrepreneurship. Bus. Horiz. 2014, 57, 37-47. [CrossRef]

40. Donald, F.K.; Montagno, R.V.; Hornsby, J.S. Developing an intrapreneurial assessment instrument for an effective corporate entrepreneurial environment. Strateg. Manag. J. 1990, 11, 49-58.

41. Hornsby, J.S.; Kuratko, D.F.; Zahra, S.A. Middle managers' perception of the internal environment for corporate entrepreneurship: Assessing a measurement scale. J. Bus. Ventur. 2002, 17, 253-273. [CrossRef]

42. Morris, M.H.; Donald, F.K.; Jeffrey, G.C. Corporate Entrepreneurship E Innovation; Cengage Learning: Mason, OH, USA, 2010.

43. Yunis, M.; Tarhini, A.; Kassar, A. The role of ICT and innovation in enhancing organizational performance: The catalysing effect of corporate entrepreneurship. J. Bus. Res. 2018, 88, 344-356. [CrossRef]

44. Bigliardi, B. The effect of innovation on financial performance: A research study involving SMEs. Innov. Manag. Policy Pract. 2013, 15, 245-255. [CrossRef]

45. Lwamba, N.M.; Bwisa, H.; Skawa, M. Exploring the effect of corporate entrepreneurship on financial performance of firms: Evidence from Kenya's manufacturing firms. Int. J. Acad. Res. Bus. Soc. Sci. 2014, 4, 352-370. [CrossRef]

46. Nybakk, E.; Jenssen, J.I. Innovation strategy, working climate, and financial performance in traditional manufacturing firms: An empirical analysis. Int. J. Innov. Manag. 2012, 16, 1250008. [CrossRef]

47. Bartolacci, F.; Castellano, N.; Cerqueti, R. The impact of innovation on companies' performance: An entropy-based analysis of the STAR market segment of the Italian stock exchange. Technol. Anal. Strateg. Manag. 2015, 27, 102-123. [CrossRef]

48. Morales, V.J.G.; Bolívar-Ramos, M.T.; Martín-Rojas, R. Technological variables and absorptive capacity's influence on performance through corporate entrepreneurship. J. Bus. Res. 2014, 67, 1468-1477. [CrossRef]

49. Hervas-Oliver, J.-L.; Sempere-Ripoll, F.; Boronat-Moll, C. Process innovation strategy in SMEs, organizational innovation and performance: A misleading debate? Small Bus. Econ. 2014, 43, 873-886. [CrossRef]

50. Eiriz, V.; Faria, A.P.; Barbosa, N. Firm growth and innovation: Towards a typology of innovation strategy. Innov. Manag. Policy Pract. 2013, 15, 97-111. [CrossRef]

51. Rouse, J.; Treanor, L.; Fleck, E. The gendering of entrepreneurship: Theoretical and empirical insights. Int. J. Entrep. Behav. Res. 2013, 19, 452-459. [CrossRef]

52. Tavassoli, S.; Karlsson, C. Persistence of various types of innovation analyzed and explained. Res. Policy 2015, 44, 1887-1901. [CrossRef]

53. Berkhout, G.; Hartman, D.G.; Trott, P. Connecting technological capabilities with market needs using a cyclic innovation model. R D Manag. 2010, 40, 474-490. [CrossRef]

54. Atalay, M.; Anafarta, N.; Sarvan, F. The relationship between innovation and firm performance: An empirical evidence from turkish automotive supplier industry. Procedia-Soc. Behav. Sci. 2013, 75, 226-235. [CrossRef]

55. Simao, L.B.; Rodrigues, R.G.; Madeira, M.J. External relationships in the organizational innovation. RAI Rev. Adm. Innov. 2016, 13, 156-165. [CrossRef]

56. Saxena, M.; Maru, S. To study the impact of determinants of growth on firm's performance with respect to It industry. Int. J. Res.-GRANTHAALAYAH 2016, 4, 108-118. [CrossRef]

57. Ambad, S.N.A.; Wahab, K.A. The relationship between corporate entrepreneurship and firm performance: Evidence from malaysian large companies. Int. J. Bus. Soc. 2017, 17, 259-280. [CrossRef]

58. Frank, H.; Kessler, A.; Fink, M. Entrepreneurial orientation and business performance-A replication study. Schmalenbach Bus. Rev. 2010, 62, 175-198. [CrossRef]

59. Pérez-Luño, A.; Wiklund, J.; Cabrera, R.V. The dual nature of innovative activity: How entrepreneurial orientation influences innovation generation and adoption. J. Bus. Ventur. 2011, 26, 555-571. [CrossRef]

60. Johannes, N. An Assessment of Corporate Entrepreneurship in the Finishing Units of Steel Manufacturer. Ph.D. Dissertation, North-West University, Potchefstroom, South Africa, 2009.

61. Rosemond, B.; Edward, M.-Y.; Moses, A.Y. An empirical analysis of the effect of entrepreneurial orientation on firm performance of auto artisans in the cape coast metropolis. Dev. Ctry. Stud. 2012, 2, 77-87. 
62. Eggers, F.; Kraus, S.; Hughes, M.; Laraway, S.; Snycerski, S. Implications of customer and entrepreneurial orientations for SME growth. Manag. Decis. 2013, 51, 524-546. [CrossRef]

63. Fatoki, O. The causes of the failure of new small and medium enterprises in South Africa. Mediterr. J. Soc. Sci. 2014, 5, 922-927. [CrossRef]

64. Oni, E.O. Relevance of entrepreneurial proactiveness on business performance: Nigerian companies experience. Arab. J. Bus. Manag. Rev. 2012, 1, 92-108.

65. Wang, Y.; Poutziouris, P. Entrepreneurial risk taking: Empirical evidence from UK family firms. Int. J. Entrep. Behav. Res. 2010, 16, 370-388. [CrossRef]

66. Balabanis, G.I.; Katsikea, E.S. Being an entrepreneurial exporter: Does it pay? Int. Bus. Rev. 2003, 12, 233-252. [CrossRef]

67. Ključnikov, A.; Belas, J.; Smrcka, L. Znaczenie podejmowania ryzyka I agresywnej konkurencji W zarządzaniu Mśp. Pol. J. Manag. Stud. 2016, 14, 129-139. [CrossRef]

68. Anderson, B.S.; Eshima, Y. The influence of firm age and intangible resources on the relationship between entrepreneurial orientation and firm growth among Japanese SMEs. J. Bus. Ventur. 2013, 28, 413-429. [CrossRef]

69. Peng, X. Risk Taking and Firm Growth. RIETI Discussion Paper 15-E-061; Research Instituite of Economy, Trade and Industri (RIETI): Tokyo, Japan, 2015.

70. Togok, S.H.; Isa, C.R.; Zainuddin, S. Enterprise risk management adoption in Malaysia: A disclosure approach. Asian J. Bus. Account. 2016, 9, 83-104.

71. Radipere, S.; Dhliwayo, S. The role of gender and education on small business performance in the south African small enterprise sector. Mediterr. J. Soc. Sci. 2014, 5, 104. [CrossRef]

72. Smith, T.M.; Reece, J.S. The relationship of strategy, fit, productivity, and business performance in a services setting. J. Oper. Manag. 1998, 17, 145-161. [CrossRef]

73. Aminu, I.M.; Shariff, M.N.M. Influence of strategic orientation on SMEs access to finance in Nigeria. Asian Soc. Sci. 2015, 11, 298-309. [CrossRef]

74. Al-Matari, E.M.; Al-Swidi, A.K.; Fadzil, F.H.B. The measurements of firm performance's dimensions. Asian J. Financ. Account. 2014, 6, 24-49. [CrossRef]

75. Kothari, C.R. Research Methodology: Methods and Techniques; New Age International: New Delhi, India, 2004.

76. Saunders, M.; Lewis, P.; Thornhill, A. Research Methods; Pearson: London, UK, 2019.

77. Naing, N.N. Determination of sample size. Malays. J. Med. Sci. 2003, 10, 84-86.

78. Yamane, T. Statistics: An Introductory Analysis; Harper and Row: New York, NY, USA, 1967.

79. Kumar, S.C.; Kothari, H. Pilot test for reliability and validity of the study on exploring factors of training effectiveness for it competency among the employees of public sector banks. Splint Int. J. Prof. 2018, 5, 33-44.

80. Field, A. Discovering Statistics Using SPSS: Book Plus Code for E Version of Text; SAGE Publications Limited: London, UK, 2009; p. 896.

81. Cohen, J. Set correlation and contingency tables. Appl. Psychol. Meas. 1988, 12, 425-434. [CrossRef]

82. Vinet, L.; Zhedanov, A. A “missing" family of classical orthogonal polynomials. J. Phys. A Math. Theor. 2011, 44, 085201. [CrossRef]

83. Galkina, T.; Chetty, S. Effectuation and networking of internationalizing SMEs. Manag. Int. Rev. 2015, 55, 647-676. [CrossRef]

84. Bluman, A.G. Elementary Statistics: A Step by Step Approach; McGraw-Hill Higher Education: New York, NY, USA, 2009.

85. Etim, J.J.; Adabu, M.U.; Ogar, C.A. Influence of entrepreneurial orientation as survival strategy for small and medium enterprises: The nigeria experience. Int. J. Econ. Commer. Manag. 2017, 5, 502-518.

86. Al-Hanakta, R.; Illés, B.C.; Dunay, A.; Abdissa, G.S.; Khalife, M.A. The Effect of Innovation on Small and Medium Enterprises: A Bibliometric Analysis. Visegrad. J. Bioecon. Sustain. Dev. 2021, 10, 35-50. [CrossRef]

87. Harun, K.; Ağca, V. Entrepreneurial orientation and performance of Turkish manufacturing FDI firms: An empirical study. Iktisat Islet. Finans. 2009, 24, 115-133.

88. Kraus, S.; Rigtering, J.P.C.; Hughes, M.; Hosman, V. Entrepreneurial orientation and the business performance of SMEs: A quantitative study from the Netherlands. Rev. Manag. Sci. 2012, 6, 161-182. [CrossRef]

89. Matchaba-Hove, T.M.; Vambe, A.K. Entrepreneurial orientation and performance of small businesses in the retail sector in the Eastern Cape Province of South Africa. J. Mark. Manag. 2014, 5, 12-39.

90. Eniola, A.A. The entrepreneur motivation and financing sources. J. Open Innov. Technol. Mark. Complex. 2021, 7, 25. [CrossRef]

91. Anjum, T.; Farrukh, M.; Heidler, P.; Tautiva, J.A.D. Entrepreneurial intention: Creativity, entrepreneurship, and university support. J. Open Innov. Technol. Mark. Complex. 2020, 7, 11. [CrossRef]

92. Lopes, J.; Oliveira, M.; Silveira, P.; Farinha, L.; Oliveira, J. Business dynamism and innovation capacity, an entrepreneurship worldwide perspective. J. Open Innov. Technol. Mark. Complex. 2021, 7, 94. [CrossRef]

93. Chandler, N.; Krajcsák, Z. Intrapreneurial Fit and Misfit: Enterprising Behavior, Preferred Organizational and Open Innovation Culture. J. Open Innov. Technol. Mark. Complex. 2021, 7, 61. [CrossRef]

94. Luo, X.; Zhou, L.; Liu, S.S. Entrepreneurial firms in the context of China's transition economy: An integrative framework and empirical examination. J. Bus. Res. 2005, 58, 277-284. [CrossRef]

95. Semrau, T.; Ambos, T.; Kraus, S. Entrepreneurial orientation and SME performance across societal cultures: An international study. J. Bus. Res. 2016, 69, 1928-1932. [CrossRef] 
96. Tang, Z.; Tang, J. Entrepreneurial orientation and SME performance in China's changing environment: The moderating effects of strategies. Asia Pac. J. Manag. 2010, 29, 409-431. [CrossRef]

97. Ziyae, B.; Sadeghi, H. Exploring the relationship between corporate entrepreneurship and firm performance: The mediating effect of strategic entrepreneurship. Balt. J. Manag. 2020, 16, 113-133. [CrossRef]

98. Fis, A.M.; Cetindamar, D. Unlocking the relationship between corporate entrepreneurship and firm performance. Entrep. Res. J. 2019, 11, 1-22. [CrossRef]

99. Vanacker, T.; Zahra, S.A.; Holmes, R.M. Corporate entrepreneurship, country institutions and firm financial performance. J. World Bus. 2021, 56, 101162. [CrossRef] 